wave and there was no provision for lowering the temperature in the chamber in which the treated flies were held. Dieldrin has been shown to have a positive temperature coefficient with Lucilia cuprina in earlier investigations.

In addition to conducting tests with adult flies, tests were also made with prepups of field and normal strains. Prepupæ were immersed for $5 \mathrm{~min}$. in emulsions of dieldrin and placed in sand following drainage. A complete hatch of flies was obtained from prepupæ of the field strains after immersion in 0.5 per cent dieldrin, but no flies emerged from prepupæ from the normal strain following treatment with 0.05 per cent dieldrin. The prepupæ from the field strains are at least ten times more resistant to dieldrin than those from the normal strain.

The demonstration of resistance to dieldrin in the two field strains of Lucilia cuprina reported here is interesting, for a very small increase in resistance has been obtained in a laboratory programme aimed at selecting for resistance to this insecticide. Laboratory selections have been made for twelve generations.

The resistance to dieldrin in the field strains could, however, explain the unsatisfactory results being obtained on the two properties concerned. In view of the rapid development of resistance of dipterous insects to dieldrin ${ }^{3}$, it is highly possible that dieldrin resistance in Lucilia cuprina will appear in other areas. The laboratory investigations have been confined to studies on dieldrin owing to the small numbers of flies available for the tests. The work will be extended to include toxicity studies with other insecticides used for sheep blowfly prevention.



\section{Tryptophan Content of Wool}

Prevrous results for the tryptophan content of wool have given results varying from 0.5 to $2.3 \mathrm{gm}$. per $100 \mathrm{gm}$. of wool ${ }^{1-7}$. In the majority of cases the tryptophan has been determined after alkaline hydrolysis of the wool. Spies and Chambers ${ }^{8}$ have shown that the determination of tryptophan in casein, after alkaline hydrolysis, is unreliable unless special precautions, such as the use of an atmosphere of hydrogen, are taken. They found that there is reaction of tryptophan with serine, threonine and cystine during hydrolysis, and, since wool contains larger amounts of these amino-acids than casein, the results are likely to be less reliable than those for casein. They developed a method for the estimation of tryptophan in intact proteins by reaction with $p$-dimethylamino-benzaldehyde in $19 \mathrm{~N}$ sulphuric acid which avoided these side reactions.

We have used a modification of this method to determine the tryptophan content of wool and have obtained very consistent results. $30 \mathrm{mgm}$. wool, of known moisture content, is added to a solution of $100 \mathrm{mgm}$. $p$-dimethylaminobenzaldehyde in $18 \cdot 1 \mathrm{~N}$ sulphuric acid and the mixture allowed to stand in the dark at room temperature with occasional shaking, until the wool dissolves. This takes about one week. The blue colour is then developed by the addition of $0.1 \mathrm{ml}$. $0.01 M$ sodium nitrite solution
Table 1. Tryptophan Content of Wool

\begin{tabular}{|l|c|c|}
\hline Wool & Fibre diam. $(\mu)$ & $\begin{array}{c}\text { gm. Tryptophan } \\
\text { per 100 gm. dry wool }\end{array}$ \\
\hline Durban merino & $16 \cdot 0$ & 1.07 \\
Port Elizabeth merino & $19 \cdot 8$ & $1 \cdot 01$ \\
64's B.A. & $21 \cdot 3$ & $0 \cdot 97$ \\
56's New Zealand & $23 \cdot 9$ & $0 \cdot 95$ \\
56 's Monterides & $30 \cdot 2$ & 0.94 \\
44's New Zealand & $34 \cdot 3$ & 0.93 \\
\hline
\end{tabular}

and estimated with a Spekker photoelectric absorptiometer using Chance $O R 2$ filters.

The tryptophan contents of a number of wool samples determined by this method are given in Table 1.

These results show that there is a tendency for the finer quality wools to contain more tryptophan than those of lower quality. This does not appear to be due to destruction by the sulphuric acid of some of the tryptophan in the coarser wools, since we have obtained the same tryptophan content for a sample of wool using sulphuric acid varying in strength from $17 \cdot 1 \mathrm{~N}$ to $23 \cdot 0 \mathrm{~N}$ and also using hydrochloric acid in place of the sulphuric acid.

The tryptophan content of a number of other keratins has been determined by this method and the results are given in Table 2 .

Table 2. Tryptophan CONTENT OF VARIOUS KnRATINS

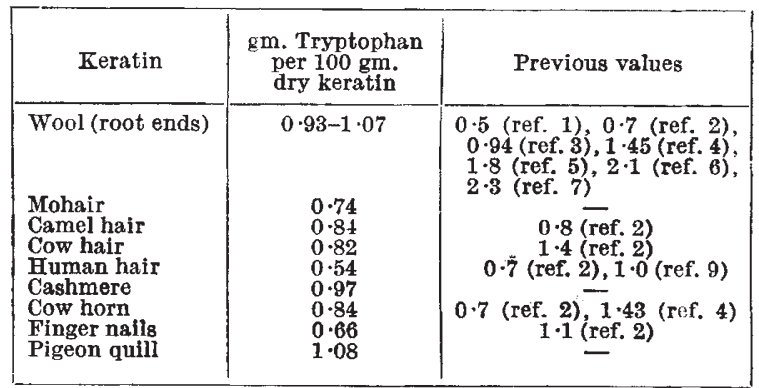

These results show that the tryptophan contents of the keratin samples examined lie between 0.5 and $1 \cdot 1$ per cent. This contrasts with the occurrence of only trace amounts of tryptophan in various colla. gens ${ }^{10,11}$ and suggests that determination of the tryptophan content of tissue proteins may be a convenient method for classifying the proteins as collagens or keratins.

We hope to publish a fuller account of this work in due course.

We wish to thank the directors of Wolsey, Ltd., for permission to publish this communication.

\section{R. Graham}

Abbey Meadow Mills,

K. W. Statham

Dyers and Finishers, Leicester.

Jan. 7.

${ }^{1}$ Mazingue, G., Decroix, G., and van Overbeke, M., Bull. Inst. Text, France, No. 61, 37 (1956).

2 Block, R. J., Bolling, D., Brand, F. C., and Schein, A., J. Biol. Chem., 1ः8, 181 (1939).

${ }^{3}$ Corfleld, M. C., and Robson, A., Biochem. J., 59, 62 (1955).

- Folin, O., and Looney, J. M., J. Biol. Chem., 51, 421 (1922).

'Marston, H. R., Australian Council Sci. Ind. Res. Bull. No. 38 (1928).

- Simmonds, D. H., Austral. J. Biol. Sci., 7, 98 (1954).

'Simmonds, D. H., Proc. Int. Wool Text. Res. Conf., Australia $C 65$ (1955).

${ }^{8}$ Spies, J. R., and Chambers, D. C., Anal. Chem., 21, 1249 (1949).

' Lang, J. M., and Lucas, C. C., Biochem. J., 52, 84 (1952).

${ }_{11}^{19}$ Beveridge, J. M. R., and Lucas, C. C., J. Biol. Chem., 155, 547 (1944). ${ }_{1}^{1}$ Bowes, J. H., and Kenten, R. H., Biochem. J.. 43, 358 (1948). 